\title{
Article \\ Effect of Organic Amendments in Soil on Physiological and Biochemical Attributes of Vachellia nilotica and Dalbergia sissoo under Saline Stress
}

\author{
Muhammad Talha Bin Yousaf ${ }^{1}$, Muhammad Farrakh Nawaz ${ }^{1}$ (D), Ghulam Yasin ${ }^{2,3}$ (D), Irfan Ahmad ${ }^{1}$ (D), Sadaf Gul ${ }^{4}$, \\ Muhammad Ijaz ${ }^{5}$, Muhammad Zia-ur-Rehman ${ }^{6}\left(\mathbb{D}\right.$, Xuebin Qi ${ }^{7, *}$ and Shafeeq Ur Rahman ${ }^{7,8, *(D)}$
}

check for

updates

Citation: Talha Bin Yousaf, M.; Farrakh Nawaz, M.; Yasin, G.;

Ahmad, I.; Gul, S.; Ijaz, M.;

Zia-ur-Rehman, M.; Qi, X.;

Ur Rahman, S. Effect of Organic

Amendments in Soil on Physiological and Biochemical Attributes of Vachellia nilotica and Dalbergia sissoo under Saline Stress. Plants 2022, 11, 228. https://doi.org/10.3390/ plants11020228

Academic Editors

Pasqualina Woodrow and Loredana

Filomena Ciarmiello

Received: 3 December 2021

Accepted: 3 January 2022

Published: 17 January 2022

Publisher's Note: MDPI stays neutral with regard to jurisdictional claims in published maps and institutional affiliations.

Copyright: (C) 2022 by the authors. Licensee MDPI, Basel, Switzerland. This article is an open access article distributed under the terms and conditions of the Creative Commons Attribution (CC BY) license (https:// creativecommons.org/licenses/by/ $4.0 /)$.
1 Department of Forestry and Range Management, University of Agriculture, Faisalabad 38000, Pakistan; talha.gorsi7@gmail.com (M.T.B.Y.); kf_uaf@yahoo.com (M.F.N.); irfan_uaf@yahoo.com (I.A.)

2 Department of Forestry, Range and Wildlife Management, The Islamia University Bahawalpur, Bahawalpur 63100, Pakistan; yasin_2486@yahoo.com

3 Department of Forestry and Range Management, Bahauddin Zakariya University, Multan 60800, Pakistan

4 Department of Botany, University of Karachi, Karachi 75270, Pakistan; sadafgpk@yahoo.com

5 Bahadur Sub Campus Layyah, College of Agriculture, Bahauddin Zakariya University, Multan 60800, Pakistan; muhammad.ijaz@bzu.edu.pk

6 Institute of Soil and Environmental Sciences, University of Agriculture, Faisalabad 38000, Pakistan; ziasindhu1399@gmail.com

7 Farmland Irrigation Research Institute, Chinese Academy of Agricultural Sciences, Xinxiang 453000, China

8 School of Environment and Civil Engineering, Dongguan University of Technology, Dongguan 523000, China

* Correspondence: qxb6301@sina.cn (X.Q.); malikshafeeq1559@gmail.com (S.U.R.)

Abstract: Vachellia nilotica (L.) P.J.H. Hurther \& Mabb. and Dalbergia sissoo Roxb. are two of the most important multipurpose agroforestry tree species of the Indian sub-continent, but their growth in saline soils is greatly reduced. Recently, organic amendments have showed the potential to increase plant growth in salt-affected soils; however, the influence of using these amendments for growing the above-mentioned tree species under saline conditions is not yet quantified. Therefore, an experiment was devised to analyze the interactive effects of organic amendments in saline soils on the growth of $V$. nilotica and D. sissoo. Under controlled conditions, a pot experiment was conducted in sandy loam saline soils $\left(\mathrm{EC}=20.5 \mathrm{dSm}^{-1}\right)$. Organic amendments from four diverse sources: farmyard manure (FYM), poultry manure (PM), slurry (SL), and farmyard manure biochar (FYMB) were employed in this study. At the harvesting time, data regarding morphological, physiological, ionic, and biochemical parameters were obtained. The current study results indicated that both tree species reacted differently, but positively, to diverse applied amendments. The maximum increment in total above-ground biomass, total below-ground biomass, and shoot length for $V$. nilotica $(163.8 \%, 116.3 \%$, and $68.2 \%$, respectively) was observed in FYM amended soils, while the maximum increment for D. sissoo (128\%, 86\%, and 107\%, respectively) was observed in FYMB amended soils, as compared to control. Minimum plant growth of both species was observed in untreated soils (saline soils). Likewise, the maximum potassium ion and minimum sodium ion concentrations were present in the root and shoots of plants (both species) treated with FYMB. The use of organic amendments resulted in decreased concentrations of malondialdehyde and hydrogen peroxide, and increased concentrations of antioxidant enzymes such as SOD, POD, and CAT. Moreover, higher photosynthetic rates and stomatal conductance were observed in the plants grown in amended soils. The findings of this study can be used to include the above-mentioned high-value tree species for future afforestation programs under saline conditions.

Keywords: soil degradation; afforestation; salinity; nursery raising; agroforestry 


\section{Introduction}

Salinity is a global issue, and the area affected by salinity is increasing persistently [1,2]. In a few countries, salinity and sodicity affect more than $50 \%$ of the cultivated land [3]. The productive area of the world is decreasing due to salinity and other abiotic stresses while the world population is increasing, raising the issue of food security [2,4]. There is therefore a dire need to find ways to make these lands productive [5,6]. Many approaches can reclaim saline soils such as engineering, chemical, and biological techniques [2,7]. Using green plants is an efficient, sustainable, and cost-effective practice to improve salt-affected soils' quality $[8,9]$. Moreover, among vegetation, trees are considered to have more potential due to their higher tolerance index, larger biomass production, and longer periods of growth [9-16]. However, only selected tree species can be grown on saline soils [17].

Under sub-tropical and semi-arid conditions, several tree species have been reported to survive under light to moderate salinity levels, such as Vachellia nilotica, Vachellia auriculiformis, Albizia lebbek, Terminalia arjuna, Prosopis juliflora, Casuarina equisetifolia, Prosopis cineraria, Tamarix indica, Dalbergia sissoo, Eucalyptus camaldulensis, Emblica officinalis, Zizyphus jujube, and Syzygium cumini $[18,19]$. Among them, $V$. nilotica and D. sissoo are farm-friendly tree species found in several parts of the world, particularly in India, Pakistan, Sri Lanka, Nepal, Australia, and Africa [20,21]. Both are highly valuable for timber, furniture, fodder, medicinal value [22], and other environmental services such as climate change mitigation, shade, beauty, soil fertility improvement, etc. $[23,24]$. Both tree species also play an important role in environmental conservation and ecosystem balance [25]. These species are reported to have the ability to tolerate saline conditions and ameliorate the soil's physicochemical properties $[26,27]$. Trees have the ability to minimize salt deposition and salt accumulation in the upper layer of soil due to higher transpiration rate of trees and lower evaporation rate under the shade of trees, respectively $[28,29]$. The deep root system of trees helps in improving the physical structure of soil and allows the translocation of sodium ions in deeper soil horizons [30,31]. However, in these types of degraded soils, trees have to face various physiological problems and their growth is reduced $[19,28]$.

Generally, saline soils have low organic matter content [32]. However, it is recently reported that several organic amendments made from agricultural wastes such as green manures, farmyard and poultry manure, agro-industrial by-products, food processing wastes, mulches, cover crops, and composts can be very helpful in improving soil health and plant growth under saline conditions [33-36]. Farmyard manure has been used to ameliorate degraded soils for several centuries and it has the potential to mitigate the negative impacts of salinity, enhance plant biomass, and increase yield [37]. Similarly, poultry manure and slurry have shown very positive results in enhancing vegetative cover on salt-degraded lands [38,39]. Biochar, a processed form of the organic amendment, has shown promising results and has resulted in increased crop yields and plant growth under saline conditions [36,40]. It is considered one of the most important discoveries in the history of mankind [40-43]. There are different types of biochar made from diverse sources under characteristic environmental conditions $[9,16,41,44]$. In another experiment, different types of biochar were applied to check their effect on the growth of three different agroforestry tree species. Among three different types of biochar, farmyard manure biochar showed the best results. It not only improved soil conditions, but also enhanced plant growth [9].

This experiment was devised to assess the impact of commonly available organic amendments (FYM, PM and SL) and processed organic amendment in the form of biochar (FYMB) on the growth of two important farm-friendly tree species: $V$. nilotica and D. sissoo under saline conditions. The result of using various organic amendments on the growth and physiological attributes of selected species were studied, and the combined ameliorative effect of the selected amendments and species on soil physicochemical properties was also studied. 


\section{Results and Discussion}

\subsection{Growth Attributes}

Figure 1 depicts the growth parameters of the selected two species with five different treatments. V. nilotica generally showed better results as compared to $D$. sissoo for all growth parameters. There was a $68 \%, 36 \%, 45 \%$, and $63 \%$ increase in the shoot length of $V$. nilotica in T2, T3, T4, and T5, respectively, as compared to T1. There was a $92 \%, 79 \%, 2.2 \%$, and $107 \%$ increase in the shoot length of D. sissoo in T2, T3, T4, and T5, respectively, as compared to $\mathrm{T} 1$. There was a $114 \%, 34 \%, 96 \%$, and $102 \%$ increase in the root length of $V$. nilotica in T2, T3, T4, and T5, respectively, as compared to T1. There was a $45 \%, 33 \%, 26 \%$, and $42 \%$ increase in the root length of D. sissoo in T2, T3, T4, and T5, respectively, compared to T1. There was a $163 \%, 65 \%, 110 \%$, and $139 \%$ increase in the total above-ground biomass of $V$. nilotica in T2, T3, T4, and T5, respectively, as compared to T1. There was a 109\%, 45\%, $5 \%$, and $128 \%$ increase in the total above-ground biomass of D. sissoo in T2, T3, T4, and $\mathrm{T} 5$, respectively, as compared to $\mathrm{T} 1$. There was a $116 \%, 24 \%, 57 \%$, and $86 \%$ increase in the below-ground biomass of $V$. nilotica in T2, T3, T4, and T5, respectively, compared to T1. There was an $86 \%, 34 \%, 55 \%$, and $102 \%$ increase in the below-ground biomass of $D$. sissoo in T2, T3, T4, and T5, respectively, as compared to T1. The general trend of $V$. nilotica with different treatments for all growth parameters was recorded as T2 $>\mathrm{T} 5>\mathrm{T} 4>\mathrm{T} 3>\mathrm{T} 1$. The general trend of D. sissoo with different treatments was recorded as T5 $>\mathrm{T} 2>\mathrm{T} 3>\mathrm{T} 4>\mathrm{T} 1$.

\subsection{Physiological Attributes}

Figure 2 depicts the effect of different organic amendments on physiological characteristics of $V$. nilotica and D. sissoo. All treatments affected the chlorophyll concentrations of plants. FYM and FYMB showed maximum SPAD values for chlorophyll contents. Chlorophyll contents of Vachellia nilotica increased by $48 \%, 31 \%, 28 \%$, and $34 \%$ in T2, T3, T4, and T5, respectively, as compared to control. Chlorophyll contents of Dalbergia sissoo increased by $31 \%, 17 \%, 10 \%$, and 40\% in FYM, PM, SL, and FYMB, respectively, as compared to control. The photosynthetic rate of both species was increased by using all types of organic amendments. The photosynthetic rate was increased by 34\%, 20\%,12\%, and 33\% for $\mathrm{V}$. nilotica against FYM, PM, SL, and FYMB, respectively. The photosynthetic rate was increased by $33 \%, 17 \%, 9 \%$, and $36 \%$ for $D$. sisso in T2, T3, T4, and T5, respectively. The maximum stomatal conductance $\left(0.07 \mathrm{~mol} \mathrm{~m}^{-2} \mathrm{~s}^{-1}\right)$ and sub-stomatal $\mathrm{CO}_{2}\left(236.11 \mu \mathrm{mol} \mathrm{m} \mathrm{m}^{-2} \mathrm{~s}^{-1}\right)$ were exhibited by the $V$. nilotica plants treated with farmyard manure. The minimum stomatal conductance $\left(0.02 \mathrm{~mol} \mathrm{~m}^{-2} \mathrm{~s}^{-1}\right)$ and sub-stomatal $\mathrm{CO}_{2}\left(179.44 \mu \mathrm{mol} \mathrm{m}^{-2} \mathrm{~s}^{-1}\right)$ were shown by the $D$. sissoo plants with the control treatment. The general trend of $V$. nilotica with different treatments for all physiological parameters was recorded as T2 $>\mathrm{T} 5>\mathrm{T} 4>\mathrm{T} 3>\mathrm{T} 1$. The general trend of $D$. sissoo with different treatments was recorded as T5 $>$ T2 $>\mathrm{T} 3>\mathrm{T} 4>\mathrm{T} 1$.

\subsection{Sodium and Potassium Contents in Plants}

The sodium $(\mathrm{Na})$ and potassium $(\mathrm{K})$ concentrations were determined for shoots and roots for both species in all treatments. The $\mathrm{Na}$ contents in shoots of $V$. nilotica were decreased by $45 \%, 31 \%, 33 \%$, and $79 \%$ in $\mathrm{T} 2$, T3, T4, and $\mathrm{T} 5$, respectively, compared to control. The concentration of $\mathrm{Na}$ in shoots of D. sissoo was decreased by $53 \%, 33 \%, 35 \%$, and $83 \%$ in $\mathrm{T} 2, \mathrm{~T} 3, \mathrm{~T} 4$, and $\mathrm{T} 5$, respectively, as compared to control.

The $\mathrm{K}$ contents ( $\left.\mathrm{mg} \mathrm{g}^{-1} \mathrm{DW}\right)$ in shoots of $\mathrm{V}$. nilotica were increased by $81 \%, 51 \%$, $65 \%$, and $111 \%$ in T2, T3, T4, and T5, respectively, compared to control. The K contents $\left(\mathrm{mg} \mathrm{g}^{-1} \mathrm{DW}\right.$ ) in shoots of D. sissoo were increased by $129 \%, 87 \%, 112 \%$, and $62 \%$ in T2, T3, T4, and T5, respectively, compared to control. Minimum sodium and maximum potassium concentrations in roots of $D$. sissoo and V. nilotica were recorded in the T5 treatment. The results of sodium and potassium concentration are illustrated in Figure 3. 


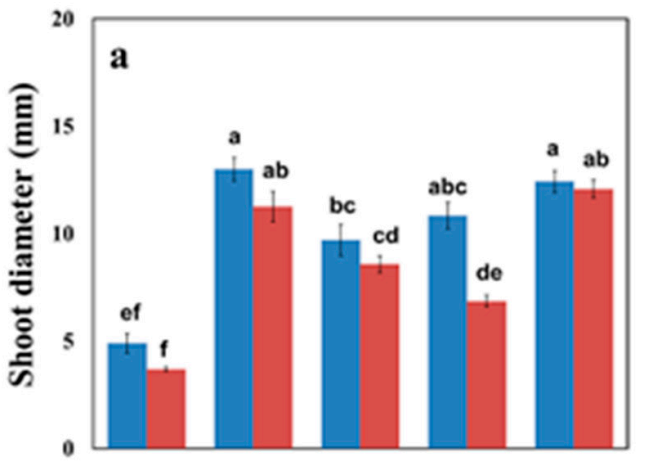

- Vachellia nilotica

- Dalbergia sissoo
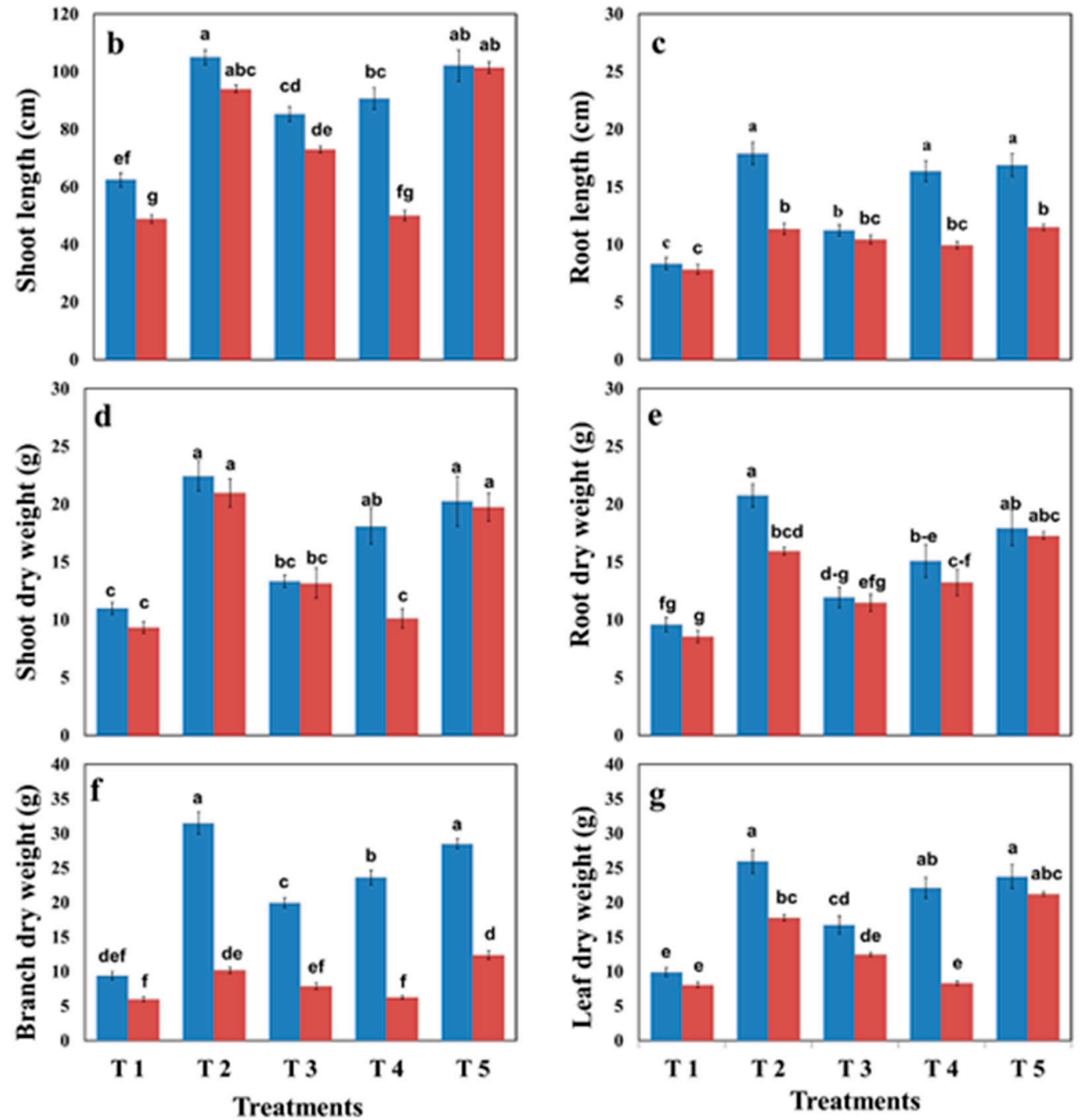

Figure 1. Effects of different organic amendments on (a) shoot diameter, (b) shoot length, (c) root length, (d) shoot dry weight, (e) root dry weight, (f) branch dry weight, and (g) leaf dry weight of Vachellia nilotica and Dalbergia sissoo, where T1 = control, T2 = farmyard manure, T3 = poultry manure, $\mathrm{T} 4$ = slurry, T5 = biochar. The lower case letters the indicate that values are significantly $(p<0.05)$ different from each other. 

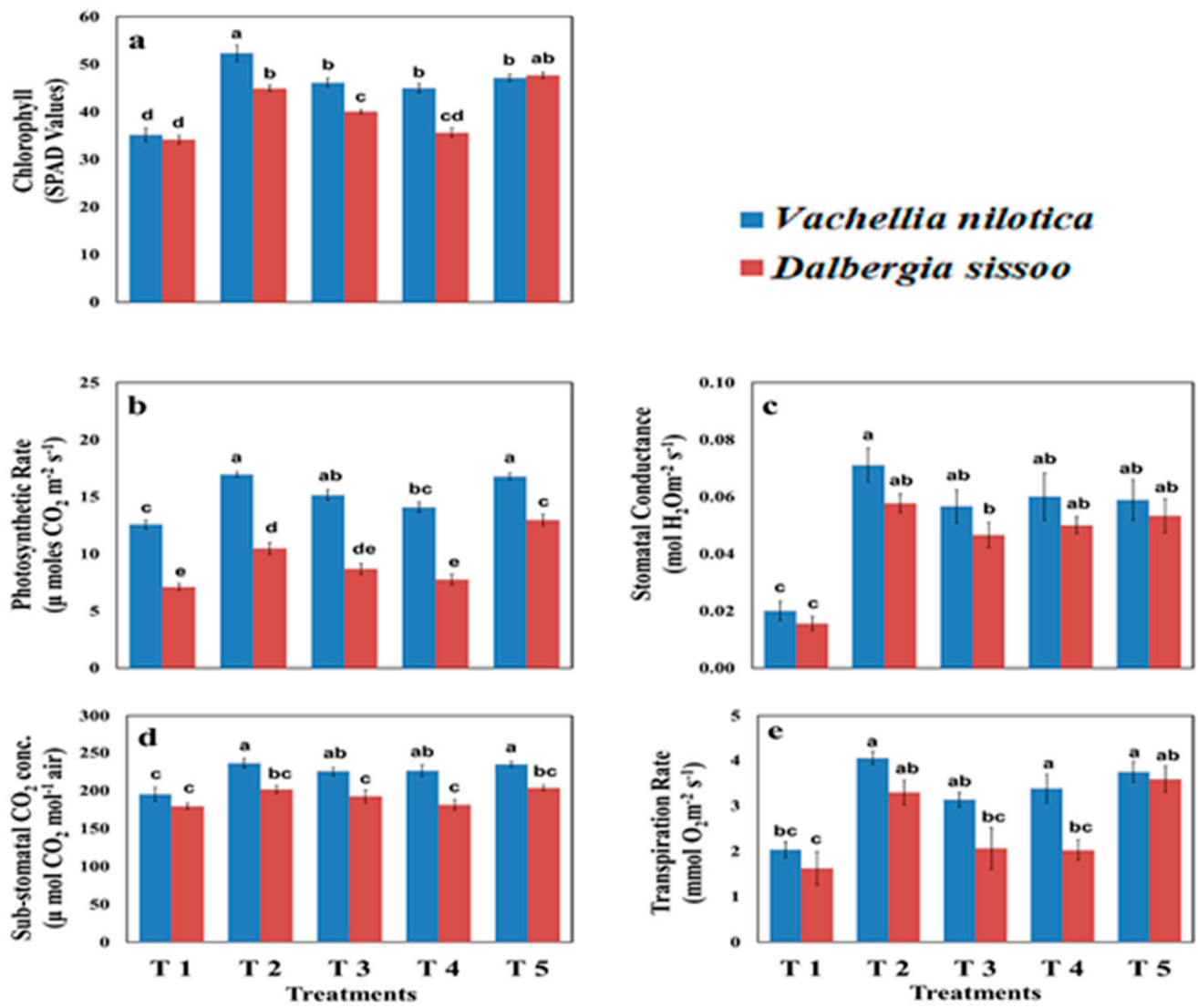

Figure 2. Effect of different organic amendments on (a) chlorophyll content, (b) photosynthetic rate, (c) stomatal conductance, (d) substomatal $\mathrm{CO}_{2}$ concentration, (e) transpiration rate of Vachellia nilotica and Dalbergia sissoo, where T1 = control, T2 = farmyard manure, T3 = poultry manure, T4 = slurry, $\mathrm{T} 5=$ biochar. The lower case letters indicate that values are significantly $(p<0.05)$ different from each other.

\subsection{Biochemical Parameters}

Figure 4 depicts the results of the effect of different organic amendments and selected tree species on selected enzymatic activities. Results indicated that all types of organic amendments enhanced antioxidant enzymatic activities as compared to control. Higher concentrations of $\mathrm{H}_{2} \mathrm{O}_{2}$ and MDA $\left(\mu \mathrm{M} \mathrm{g}^{-1} \mathrm{FW}\right)$ were found in the plants of control treatment, whereas organic amendments reduced the concentration of $\mathrm{H}_{2} \mathrm{O}_{2}$ and MDA, but results were not statistically significant for different types of organic amendments. The minimum concentration of antioxidant enzymatic activities was present in the D. sissoo plants. The maximum increments in SOD $(68.76 \%)$ and CAT $(38.20 \%)$ activities were found in the D. sissoo plants with the T5 treatment. POD activities were not affected significantly by using different organic amendments.

\subsection{Post-Harvest Soil Characteristics}

The current study results demonstrate that post-harvest characteristics of soils are significantly affected by using different types of organic amendments. The minimum value of $\mathrm{pH}$ was observed in the plants of control treatment; although $\mathrm{pH}$ was significantly reduced as compared to initial soil characteristics, there was no significant difference among different treatments for the value of $\mathrm{pH}$ after harvesting of plants. 

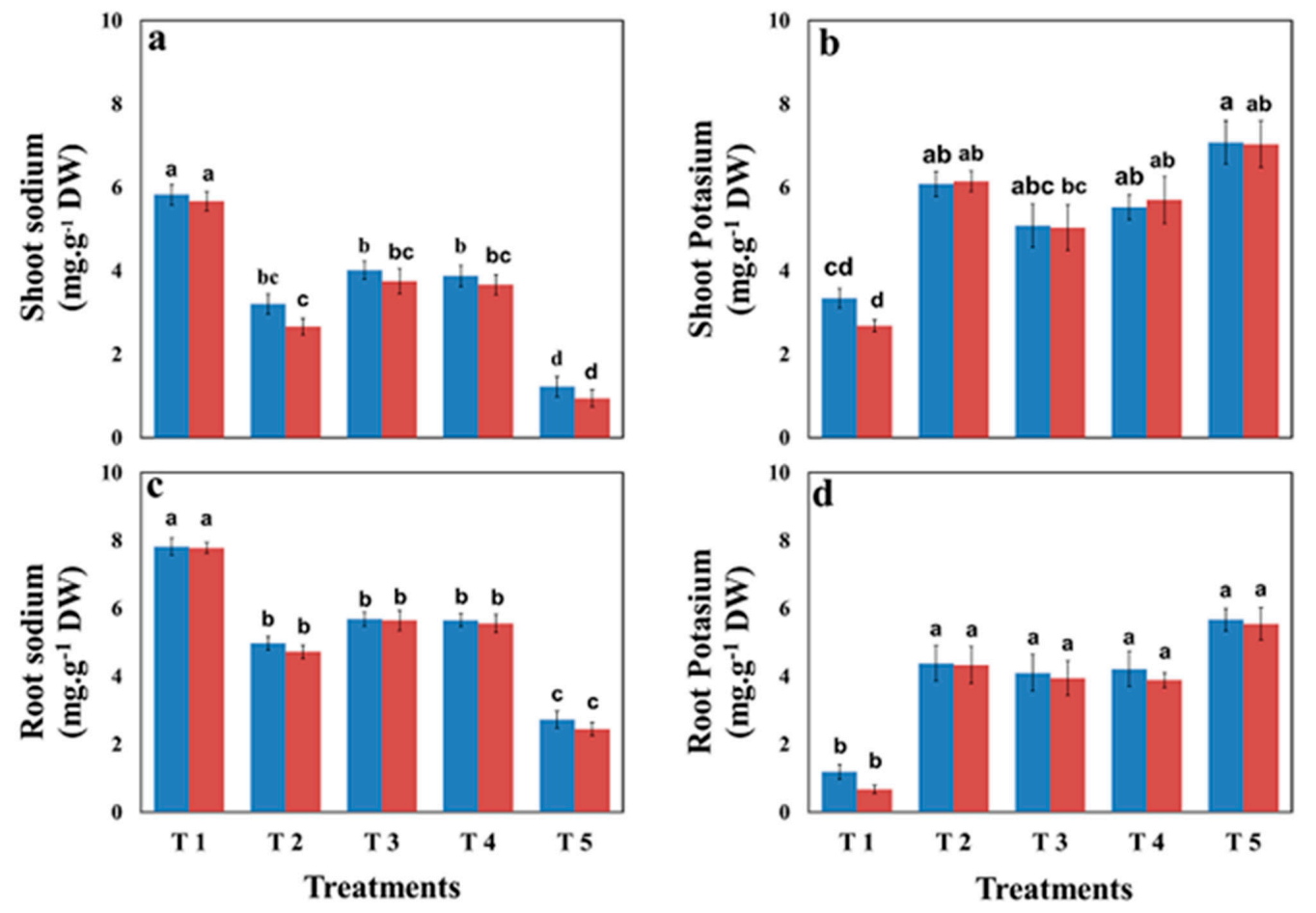

Vachellia nilotica Dalbergia sissoo

Figure 3. Effect of different organic amendments on (a) shoot sodium, (b) shoot potassium, (c) root sodium, and (d) root potassium of Vachellia nilotica and Dalbergia sissoo, where T1 = control, T2 = farmyard manure, $\mathrm{T} 3$ = poultry manure, $\mathrm{T} 4=$ slurry, $\mathrm{T} 5=$ biochar. The difference between lower case letters is the indication that values are significantly $(p<0.05)$ different from each other.

Maximum electrical conductivity was found in the plants of the control treatment. All types of applied organic amendments showed very promising results in reducing the values of EC and improving the physicochemical characteristics of the soil. All types of organic amendments were found to be helpful in reducing the values of the total soluble salts (TSS) and the sodium adsorption ratio (SAR). The use of organic amendments also improved the organic matter and saturation percentages. It was also observed that the concentration of potassium and calcium ions was increased and the concentration of sodium ions was decreased by applying different types of organic matter as a soil amendment. Among different types of applied organic amendments, biochar showed the most promising results in reducing the values of EC, TSS, SAR, and sodium ions. Furthermore, biochar was also the best amendment to improve the organic matter contents of soil, saturation percentage, and concentration of potassium ions. Data regarding different post-harvest soil characteristics are given in Table 1. We can say that all types of applied organic amendments were beneficial in improving the physicochemical characteristics of soil, but biochar showed the best results.

Among trees species, Vachellia nilotica showed the best results as compared to Dalbergia sissoo in terms of improved physicochemical characteristics, as it can be seen from the table that the EC reduced from $20.5 \mathrm{dS} / \mathrm{m}-12.41 \mathrm{dS} / \mathrm{m}$ in the soil where $D$. sissoo was grown without any amendment, whereas the EC of soil decreased from $20.5 \mathrm{dS} / \mathrm{m}$ to $8.71 \mathrm{dS} / \mathrm{m}$ of untreated $V$. nilotica soil. Similar results were obtained for all other parameters. These results show that the phytoremediation potential of $V$. nilotica is greater than Dalbergia sisoo for ameliorating salt degraded lands and biochar is the best amendment to improve the physicochemical properties of soil. 

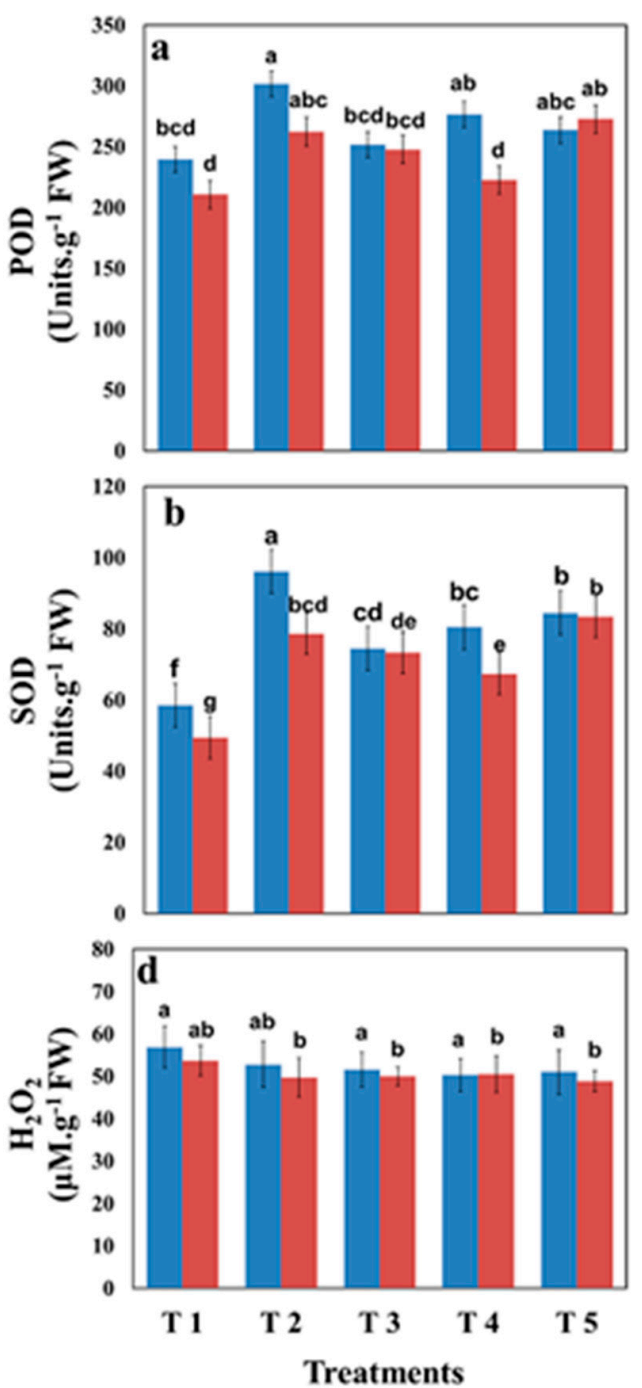

Vachellia nilotica

Dalbergia sissoo
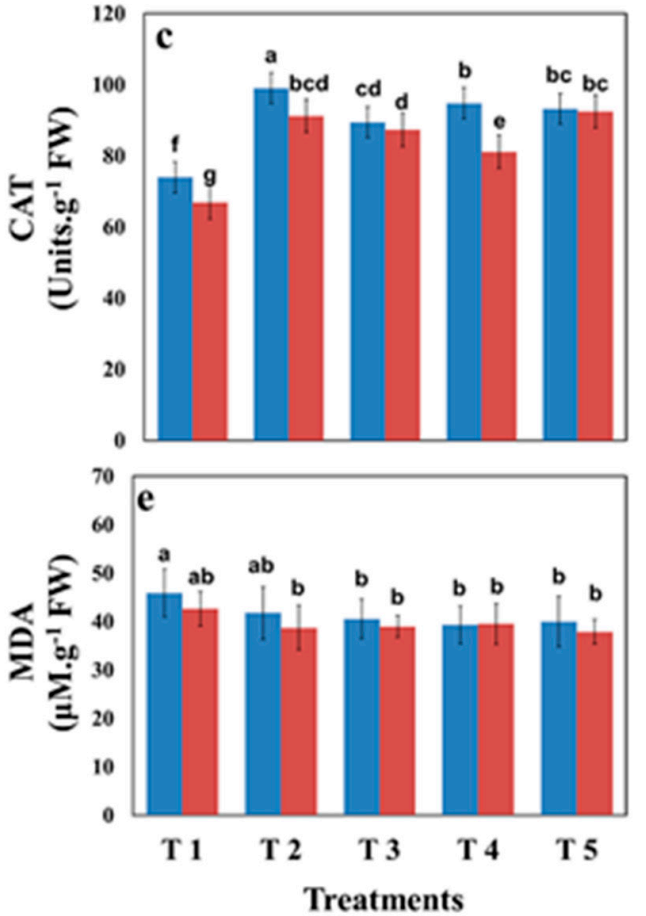

Figure 4. Effect of different organic amendments on (a) peroxidase (POD), (b) superoxide dismutase (SOD), (c) catalase (CAT) activities, concentrations of $(\mathbf{d})$ hydrogen peroxide $\left(\mathrm{H}_{2} \mathrm{O}_{2}\right)$ in plants' leaves, and (e) malondialdehyde (MDA). T1 = control, T2 = farmyard manure, T3 = poultry manure, $\mathrm{T} 4$ = slurry, $\mathrm{T} 5=$ biochar. The difference between lower case letters is the indication that values are significantly $(p<0.05)$ different from each other.

The results of this study represent the salinity tolerance potential of two important agroforestry species (Vachellia nilotica and Dalbergia sissoo) and, at the same time, the effects of three commonly found organic wastes (farmyard manure, poultry manure, and slurry) and one processed organic amendment, in the form of biochar, on the growth and physiology of these species along with the physicochemical properties of soil. Results indicated that salinity negatively affected the plant's growth. Almost all morphological and growth parameters such as shoot length, root length, dry weight of root, shoots, leaves, and branches were less in the control treatment plants (under salinity). The reduction in growth is due to a higher concentration of salts in saline soils. The osmotic potential of salt-affected soils is low and when plants are grown in this soil, they must keep their internal osmotic potential low to avoid exosmosis. This, in turn, leads to oxidative stress and dehydration [45-48]. Salinity stress also causes nutrient imbalance, and nutrients such as $\mathrm{N}, \mathrm{Ca}, \mathrm{K}$, and toxic ions replace $\mathrm{P}, \mathrm{Fe}, \mathrm{Zn}$, and as a result, their uptake to shoot is decreased [49-51].

Different species responded to salinity in different ways, as Vachellia nilotica showed better growth as compared to Dalbergia sissoo and was found to be more effective in the remediation of saline soils. The response of plants to salinity is species and genotype- 
dependent [52]. This may be due to difference in the root behavior and hardiness of these species towards such an adverse soil environment. The differences in the salinity tolerance in these two species may be due to different rates of salt transport to the shoots, which adversely affects leaf growth, reducing the photosynthetic efficiency of the plants [53]. In another experiment, seedlings of Vachellia nilotica and Acacia ampliceps were grown under different salinity levels of up to $400 \mathrm{mM} \mathrm{NaCl}$ concentration and all growth parameters were reduced at the time of harvesting [20].

Although all the amendments showed better results for both species than control, both species' responses to different amendments were different. Farmyard manure showed the most promising results for the growth of $V$. nilotica, whereas FYMB was the best amendment for the growth of $D$. sissoo. Likewise, slurry showed better results for $V$. nilotica as compared to poultry manure, but results were the opposite for $D$. sissoo, where poultry manure showed better results than slurry. Therefore, we can say that response of plants to different organic amendments is species-specific. It was reported that the response of six different woody seedlings was species-specific under organic fertilization [54]. Likewise, five different ornamental plant species responded differently to applying the same organic matter [55]. In another study, a meta-analysis was performed and it was reported that the first-year crop yield of different agronomic crops is different for different commonly used organic amendments [56]. Plant growth of Corymbia maculata and Eucalyptus torquata was not the same for applied organic amendments. Eucalyptus torquata showed better results than control after using organic amendments, whereas Corymbia maculate did not show any significant results after applying the same amendment [57]. Among different types of biochar, sugarcane bagasse biochar showed the better results for the growth of $D$. sissoo, whereas woodchips biochar was more effective for the growth of V. nilotica [9].

The current study results revealed that minimum $\mathrm{Na}$ and maximum $\mathrm{K}$ concentrations were found in the plant parts treated with biochar. Biochar improved potato crop yield by decreasing Na contents and increasing K contents [58]. Biochar is reported to significantly enhance the concentration of potassium in leaf sap of maize [59]. Biochar showed the ability to increase the amount of available potassium and reduce the bioavailability of sodium ions [60]. Biochar application increased the available $\mathrm{K}$ and resultantly enhanced the biomass of lentils [61]. Biochar has the ability to reduce toxic elements by the process of adsorption [62]. Salt-affected soil amended with farmyard and poultry manures for rice showed enhanced growth and yield, increased amounts of potassium and $\mathrm{K} / \mathrm{Na}$, and increased salt-tolerance [63].

The use of organic amendments increased antioxidant enzymatic activities (SOD, POD, and CAT). This shows the enhanced tolerance of plants to salinity stress [64]. The antioxidant defense system of spinach leaves was also increased by using biochar and other amendments [65]. Moreover, different organic and inorganic amendments significantly increased antioxidant enzymatic activities in Zea mays against cadmium contamination [66]. In addition, the use of organic amendments, including biochar, improved mung bean antioxidant defense systems [67].

All amendments showed better results for chlorophyll contents and other gas exchange parameters for both species compared to control. It was reported that biochar increased the stomatal conductance and photosynthetic rate of okra plants [68], fava beans [69], and maize plants [70]. Photosynthetic activity and other physiological parameters of plants are also reported to be enhanced by the use of organic amendments [71]. 
Table 1. Effect of various organic amendments and agroforestry trees species on post-harvest soil characteristics.

\begin{tabular}{|c|c|c|c|c|c|c|c|c|c|c|}
\hline \multirow{2}{*}{ Parameters } & \multicolumn{2}{|c|}{ T1 } & \multicolumn{2}{|c|}{$\mathrm{T} 2$} & \multicolumn{2}{|c|}{ T3 } & \multicolumn{2}{|c|}{ T4 } & \multicolumn{2}{|c|}{ T5 } \\
\hline & SP 1 & SP 2 & SP 1 & SP 2 & SP 1 & SP 2 & SP 1 & SP 2 & SP 1 & SP 2 \\
\hline $\mathrm{pH}$ & $7.77 a \pm 0.04$ & $7.77 \mathrm{a} \pm 0.04$ & $7.87 \mathrm{a} \pm 0.04$ & $7.88 \mathrm{a} \pm 0.04$ & $7.87 \mathrm{a} \pm 0.04$ & $7.89 a \pm 0.04$ & $7.85 a \pm 0.04$ & $7.87 \mathrm{a} \pm 0.04$ & $7.84 a \pm 0.04$ & $7.84 a \pm 0.04$ \\
\hline $\mathrm{EC}(\mathrm{dS} / \mathrm{m})$ & $8.71 \mathrm{~b} \pm 0.2$ & $12.4 \mathrm{a} \pm 0.2$ & $3.94 \mathrm{de} \pm 0.2$ & $8.42 b \pm 0.2$ & $6.83 c \pm 0.2$ & $8.75 b \pm 0.2$ & $4.13 \mathrm{de} \pm 0.2$ & $8.15 b \pm 0.2$ & $3.57 \mathrm{e} \pm 0.2$ & $4.53 \mathrm{e} \pm 0.2$ \\
\hline $\operatorname{TSS}\left(\mathrm{mmol}_{\mathrm{c}} / \mathrm{L}\right)$ & $87.10 \mathrm{~b} \pm 2.1$ & $124.1 \mathrm{a} \pm 2.1$ & $39.3 \mathrm{de} \pm 2.1$ & $84.2 \mathrm{~b} \pm 2.1$ & $68.3 c \pm 2.1$ & $87.5 b \pm 2.1$ & $41.3 \mathrm{de} \pm 2.1$ & $81.5 b \pm 2.1$ & $35.7 \mathrm{e} \pm 2.1$ & $45.2 \mathrm{e} \pm 2.1$ \\
\hline $\mathrm{HCO}_{3}-\left(\mathrm{mmol}_{\mathrm{c}} / \mathrm{L}\right)$ & $4.44 a \pm 0.3$ & $4.51 \mathrm{a} \pm 0.3$ & $3.2 \mathrm{~b} \pm 0.3$ & $3.5 \mathrm{ab} \pm 0.3$ & $3.6 \mathrm{~b} \pm 0.3$ & $3.7 a b \pm 0.3$ & $3.2 \mathrm{ab} \pm 0.3$ & $3.8 \mathrm{ab} \pm 0.3$ & $3.2 b \pm 0.3$ & $3.5 a b \pm 0.3$ \\
\hline $\mathrm{Cl}^{-}\left(\mathrm{mmol}_{\mathrm{c}} / \mathrm{L}\right)$ & $51.0 \mathrm{~b} \pm 1.7$ & $60.0 \mathrm{a} \pm 1.7$ & $19.3 \mathrm{fg} \pm 1.7$ & $28.6 \mathrm{cde} \pm 1.7$ & $31.3 \mathrm{~cd} \pm 1.7$ & $34.6 \mathrm{~cd} \pm 1.7$ & $22.6 \mathrm{efg} \pm 1.7$ & $27.3 \mathrm{de} \pm 1.7$ & $17.3 \mathrm{~g} \pm 1.7$ & $25.4 \mathrm{def} \pm 1.7$ \\
\hline $\mathrm{Ca}^{2+}+\mathrm{Mg}^{2+}\left(\mathrm{mmol}_{\mathrm{c}} / \mathrm{L}\right)$ & $3.7 \mathrm{c} \pm 0.7$ & $3.83 \mathrm{bc} \pm 0.7$ & $7.5 \mathrm{a} \pm 0.7$ & $7.5 a \pm 0.7$ & $7.1 \mathrm{a} \pm 0.7$ & $6.6 \mathrm{a} \pm 0.7$ & $6.4 \mathrm{ab} \pm 0.7$ & $6.6 \mathrm{ab} \pm 0.7$ & $5.0 \mathrm{abc} \pm 0.7$ & $5.2 \mathrm{abc} \pm 0.7$ \\
\hline $\mathrm{Na}^{+}\left(\mathrm{mmol}_{\mathrm{c}} / \mathrm{L}\right)$ & $51.0 \mathrm{~b} \pm 1.2$ & $62.33 a \pm 1.2$ & $22.3 \mathrm{fg} \pm 1.2$ & $35.0 \mathrm{~d} \pm 1.2$ & $28.0 \mathrm{e} \pm 1.2$ & $37.3 \mathrm{~cd} \pm 1.2$ & $25.0 \mathrm{e} \pm 1.2$ & $40.3 c \pm 1.2$ & $18.5 \mathrm{~h} \pm 1.2$ & $19.9 \mathrm{gh} \pm 1.2$ \\
\hline SAR & $37.4 b \pm 1.3$ & $45.5 \mathrm{a} \pm 1.3$ & $11.7 \mathrm{e} \pm 1.3$ & $18.0 \mathrm{~cd} \pm 1.3$ & $14.9 \mathrm{de} \pm 1.3$ & $20.6 \mathrm{c} \pm 1.3$ & $13.9 \mathrm{de} \pm 1.3$ & $22.1 \mathrm{c} \pm 1.3$ & $11.6 \mathrm{e} \pm 1.3$ & $12.3 \mathrm{e} \pm 1.3$ \\
\hline $\mathrm{K}^{+}\left(\mathrm{mmol}_{\mathrm{c}} / \mathrm{L}\right)$ & $6.5 c \pm 0.4$ & $6.0 \mathrm{c} \pm 0.4$ & $11.3 \mathrm{a} \pm 0.4$ & $11.4 a \pm 0.4$ & $10.3 a b \pm 0.4$ & $10.4 \mathrm{ab} \pm 0.4$ & $9.5 b \pm 0.4$ & $9.4 \mathrm{~b} \pm 0.4$ & $11.6 \mathrm{a} \pm 0.4$ & $12.0 \mathrm{a} \pm 0.4$ \\
\hline $\mathrm{OM}(\%)$ & $0.51 \mathrm{e} \pm 0.1$ & $0.50 \mathrm{e} \pm 0.1$ & $0.69 \mathrm{bc} \pm 0.1$ & $0.66 \mathrm{~cd} \pm 0.1$ & $0.64 \mathrm{~cd} \pm 0.1$ & $0.63 \mathrm{~d} \pm 0.1$ & $0.62 \mathrm{~d} \pm 0.1$ & $0.63 \mathrm{~d} \pm 0.1$ & $0.77 \mathrm{a} \pm 0.1$ & $0.74 a b \pm 0.1$ \\
\hline Saturation (\%) & $34.5 \mathrm{~d} \pm 0.47$ & $34.5 \mathrm{~d} \pm 0.5$ & $39.6 \mathrm{~b} \pm 0.5$ & $38.8 \mathrm{~b} \pm 0.5$ & $37.6 c \pm 0.5$ & $37.6 c \pm 0.5$ & $38.5 b c \pm 0.5$ & $38.5 b c \pm 0.5$ & $45.4 \mathrm{a} \pm 0.5$ & $45.3 a \pm 0.5$ \\
\hline
\end{tabular}

Mean value $(n=3)$; \pm standard error; significant difference based on $p<0.05$; the lower case letters indicate that values are significantly $(p<0.05)$ different from each other. T1, control

T2, farmyard manure; T3, poultry manure; T4, slurry; T5, Biochar. SP1 = Vachellia nilotica, SP2 = Dalbergia sissoo. 
All organic amendments generally improved soil physicochemical characteristics of saline soils, with biochar showing the best results in this study. Suppose that organic amendments are used to treat salt-affected soils. In that case, they have several benefits to improve the quality of soil, such as increased water holding capacity [72], enhanced soil fertility [73], increased organic carbon [74,75], improved cation exchange capacity (CEC), decreased electrical conductivity [9,76,77], structural stability, [78,79], reduction in soil compaction [80], and enhancement of different enzymatic activities such as urease, alkaline phosphatase, and catalase activities [81,82].

Biochar application reduced the uptake of sodium ions $\left(\mathrm{Na}^{+1}\right)$, enhanced uptake of potassium ions $\left(\mathrm{K}^{+}\right)$[83-85], influenced processes of $\mathrm{Na}^{+1}$ leaching, and decreased the sodium adsorption ratio (SAR) and electrical conductivity (EC) $[84,86,87]$.

When coastal saline soils are treated with biochar, sodium can be substituted by beneficial ions such as potassium, magnesium, and calcium on the soil colloids [88]. Soil chemical properties such as $\mathrm{pH}$ and CEC were significantly affected by the interactive effect of biochar and farmyard manure, and available potassium was also increased $[19,89]$.

\section{Materials and Methods}

An experimental area of the Department of Forestry and Range Management (FRM), University of Agriculture Faisalabad (UAF) $\left(31^{\circ} 25^{\prime} 57^{\prime \prime}\right.$ N, $73^{\circ} 04^{\prime} 21^{\prime \prime}$ E) was selected for this experiment. Two-month-old seedlings of Vachellia nilotica and Dalbergia sissoo were planted in earthen pots. This experiment was conducted for a period of six months. Climatic conditions during the experiment are given in Table 2.

Table 2. Climatic conditions data during experimental months.

\begin{tabular}{cccccc}
\hline Month & $\begin{array}{c}\text { Average Max. Temp. } \\
\left({ }^{\circ} \mathbf{C}\right)\end{array}$ & $\begin{array}{c}\text { Average Min. Temp. } \\
\left({ }^{\circ} \mathbf{C}\right)\end{array}$ & $\begin{array}{c}\text { Precipitation } \\
(\mathbf{m m})\end{array}$ & $\begin{array}{c}\text { Sunshine Duration } \\
(\text { Hours })\end{array}$ & $\begin{array}{c}\text { ET }_{\mathbf{0}} \\
(\mathbf{m m})\end{array}$ \\
\hline March & 27.3 & 14.2 & 16.2 & 07.2 & 02.7 \\
April & 37.7 & 20.9 & 28.3 & 09.2 & 10.4 \\
May & 41.1 & 26.0 & 10.1 & 09.38 & 05.7 \\
June & 39.8 & 27.3 & 41.6 & 07.0 & 05.3 \\
July & 38.5 & 28.9 & 66 & 07.9 & 04.0 \\
August & 38.1 & 28.6 & 63.8 & 07.2 \\
\hline
\end{tabular}

Soil samples from different localities of Faisalabad district were collected and analyzed, and soil with low productivity and high electrical conductivity value was chosen for this study. The procedure of selecting the fields for soil collection and preparation of soil for experiments was discussed earlier in [19]. Sandy loam soil with $60 \%$ sand, $25 \%$ silt, and $15 \%$ clay was used in this experiment. Different soil physicochemical characteristics were determined according to the procedures described by the US Salinity Laboratory Staff 1954 [90]. The hydrometer method described by [91] was followed for the determination of soil texture. The $\mathrm{pH}$ was measured using a Jenway $\mathrm{pH}$ meter (Model-671P) following calibration with two buffer solutions of $\mathrm{pH} 4.00$ and 9.00. The EC was measured using a Jenway conductivity meter (Model-4070) following calibration with a $0.01 \mathrm{~N} \mathrm{KCl}$ solution. The EC was converted into total soluble salts using the graph on page 12 of the USDA Handbook No. 60 [90].

Soluble Ca and $\mathrm{Mg}$ were determined by titrating the saturation extract with $0.01 \mathrm{~N}$ EDTA (disodium) solution to a blue endpoint using Erichrome Black T indicator in the presence of $\mathrm{NH}_{4} \mathrm{OH}+\mathrm{NH}_{4} \mathrm{Cl}$ buffer solution. Soluble $\mathrm{Na}$ and $\mathrm{K}$ were determined using a Jenway PFP-7 flame photometer with $\mathrm{Na}$ or $\mathrm{K}$ filters in place. The instrument was calibrated with a series of $\mathrm{Na}$ or K (0-20 ppm) standards. Standards graphs were separately plotted for $\mathrm{Na}$ and $\mathrm{K}$ containing standards and flame photometer readings. Carbonate content was determined by titrating a saturation extract with $0.01 \mathrm{~N} \mathrm{H}_{2} \mathrm{SO}_{4}$ to a colorless endpoint using Phenolphthalein as an indicator. Bicarbonate content was determined by titrating an aliquot obtained after $\mathrm{CO}_{3}{ }^{2-}$ determination with $0.01 \mathrm{~N} \mathrm{H}_{2} \mathrm{SO}_{4}$ to a pinkish yellow endpoint using methyl orange as an indicator. Soluble chloride content was deter- 
mined by titrating the aliquot after $\mathrm{HCO}_{3}{ }^{-}$determination with $0.01 \mathrm{~N} \mathrm{AgNO}$ solution to a brick red endpoint using potassium chromate $\left(\mathrm{K}_{2} \mathrm{CrO}_{4}\right)$ as an indicator. Soil OM was determined following the Walkly-Black method described in [92]. The characteristics of the soil used in this experiment are given in Table 3.

Table 3. Analysis of selected parameters for soil and other organic amendments used in the experiment.

\begin{tabular}{cccccc}
\hline Parameters & Soil & FYM & PM & SL & FYMB \\
\hline $\mathrm{pH}$ & $8.5 \pm 0.3$ & $5.8 \pm 0.2$ & $6.3 \pm 0.3$ & $6.0 \pm 0.3$ & $7.0 \pm 0.2$ \\
$\mathrm{EC}(\mathrm{dS} / \mathrm{m})$ & $20.5 \pm 9$ & $6.55 \pm 2.5$ & $7.31 \pm 3.2$ & $6.82 \pm 3.8$ & $2.08 \pm 0.34$ \\
$\mathrm{TSS}(\mathrm{mg} / \mathrm{kg})$ & $205 \pm 20$ & $65 \pm 5.8$ & $73.1 \pm 10.2$ & $68.2 \pm 8.4$ & $20.8 \pm 4.2$ \\
$\mathrm{CO}_{3}^{2-}(\mathrm{mg} / \mathrm{kg})$ & $10 \pm 2$ & $(-)$ & $(-)$ & $(-)$ & $(-)$ \\
$\mathrm{HCO}_{3-}(\mathrm{mg} / \mathrm{kg})$ & $30 \pm 4$ & $10 \pm 3.2$ & $6 \pm 3.8$ & $12 \pm 4.5$ & $8 \pm 2.5$ \\
$\mathrm{Cl}^{-}(\mathrm{mg} . \mathrm{kg}-1)$ & $140 \pm 19$ & $8.0 \pm 2.2$ & $5 \pm 3.2$ & $5 \pm 3.2$ & $4 \pm 2.1$ \\
$\mathrm{Ca}^{2+}+\mathrm{Mg}^{2+}(\mathrm{mg} / \mathrm{kg})$ & $12 \pm 4.5$ & $7.3 \pm 4.2$ & $6.3 \pm 3.1$ & $6.9 \pm 2.5$ & $13.2 \pm 2.2$ \\
$\mathrm{Na}^{+}(\mathrm{mg} / \mathrm{kg})$ & $160 \pm 15.2$ & $11.6 \pm 1.8$ & $15.2 \pm 3.4$ & $13.4 \pm 2.5$ & $3.4 \pm 0.8$ \\
$\mathrm{~K}^{+}(\mathrm{mg} / \mathrm{kg})$ & $47 \pm 7$ & $9.2 \pm 2.7$ & $8.8 \pm 2.5$ & $8.9 \pm 2.9$ & $7.2 \pm 2.2$ \\
$\mathrm{OM}(\%)$ & $0.64 \pm 0.03$ & $50.8 \pm 2.4$ & $67.2 \pm 5.5$ & $65.4 \pm 4.3$ & $95.4 \pm 3.6$ \\
\hline
\end{tabular}

Four types of commonly available organic amendments—-farmyard manure (FYM), poultry manure (PM), slurry (SL), and farmyard manure biochar (FYMB)—were applied in this experiment. Farmyard manure (FYM) is a fertilizer composed of waste products, typically dung and urine, produced by farm animals, most commonly cows and buffaloes. Poultry manure (PM), also known as chicken manure, mainly comprised of feces of chicken, is also an excellent soil amendment. Slurry (SL) is obtained as a byproduct of biogas. A biogas digester/reactor converts dung into biogas and bioslurry is produced.

These amendments were collected from the farm area of the agronomy department of the UAF. Dung cakes were used as feedstock material to prepare biochar. Biochar was prepared at $450{ }^{\circ} \mathrm{C}$ for the duration of $3 \mathrm{~h}$ under slow pyrolysis conditions.

These organic amendments were thoroughly mixed with the soil of the selected field at the rate of $6 \%(w / w)$. Characteristics of the amendments used in this experiment are given in Table 3.

Uniform-sized, healthy, and disease-free seedlings of the Vachellia nilotica (SP 1) and Dalbergia sissoo (SP 2) were collected from the nursery of the Department of FRM, UAF. They were planted in pots containing soil mixed with organic amendments. The internal diameter and height of the pots were 10 inches, and each pot contained $10 \mathrm{~kg}$ of soil. Tap water with $\mathrm{pH}(7.29), \mathrm{EC}(0.669 \mathrm{dS} / \mathrm{m})$, and RSC (1.8) was used to irrigate the plants from the nursery of the Forestry Department, UAF. Plants were irrigated with almost a half-liter of water on alternate days for each pot during the first two months. After that, from May to August, plants were irrigated with a half-liter of water on a daily basis.

The total number of treatments for this experiment was five: control (T1), FYM (T2), PM (T3), SL (T4), and FYMB (T5). There were three replications of each treatment, and for each replication, three plants were selected. Thus, nine plants were selected for each treatment for both species.

Vernier calipers and measuring tape were used to measure shoot diameter and shoot length of plants before harvesting. Both plant species' growth parameters and morphological characteristics were determined according to the earlier patterns $[16,19,93]$. An LCA-4 ADC portable infrared gas analyzer (Analytical Development Company, Hoddesdon, England) was used to measure the gas exchange parameters. Each plant's second upper fully expanded leaf was selected to measure photosynthetic parameters such as photosynthetic rate, stomatal conductance, sub-stomatal conductance, and transpiration rate measured according to the procedures described earlier in $[9,94]$. To ensure unchanged photon flux density and temperature, readings were made at a similar time each day (between 10:00 a.m. and 12:00 p.m.) by clamping the central part of the leaf in the chamber of the instrument. In terms of SPAD values, chlorophyll measurement was also performed on the third upper leaf using a chlorophyll meter (SPAD-502, Konika Minolta Sensing Inc., Tokyo, Japan). 
To estimate hydrogen peroxide content in leaves, $50 \mathrm{mg}$ of leaf sample was taken and standardized with $3 \mathrm{~mL}$ of phosphate buffer solution. This sample was then mixed with $1 \mathrm{~mL}$ of titanium sulphate in $20 \%(v / v) \mathrm{H}_{2} \mathrm{SO}_{4}$. Next, this mixture was subjected to a centrifugation process at $6000 \times g$ resolution for a period of $15 \mathrm{~min}$. After that, the absorption of the supernatant was calculated using a spectrophotometer at the wavelength of $410 \mathrm{~nm}$. To calculate malondialdehyde contents of leaves, a $0.2 \mathrm{~g}$ leaf sample was homogenized in $5 \mathrm{~mL}$ of trichloroacetic acid (TCA). After that, this sample was passed through the process of centrifugation at $10,000 \times g$ of resolution for a period of $20 \mathrm{~min}$. In the end, the absorption of supernatant was calculated at three different wavelengths, namely 450, 532 and 600, to estimate leaf MDA contents by using the following equation. The details of the determination of the biochemical parameters are given in [94,95].

$$
\mathrm{C}\left(\mu \mathrm{mol} \mathrm{L}{ }^{-1}\right)=6.45(\mathrm{~A} 532-\mathrm{A} 600)-0.56 \mathrm{~A} 450
$$

$0.2 \mathrm{~g}$ leaf samples were taken and mixed with $0.05 \mathrm{M}$ buffer solution of phosphate to determine the activities of SOD and POD. The mixture was passed through the process of centrifugation at $12,000 \times g$ resolution for a period of $20 \mathrm{~min}$. The detailed procedure for determining the activities of SOD and POD is described earlier in [96,97], while CAT activity was determined according to the procedure described earlier in [98].

Roots, shoots, and leaves were separately oven-dried at $75^{\circ} \mathrm{C}$ till the constant weight was obtained. Oven-dried plant material was ground and then digested using nitric acid and perchloric acid. According to the procedures explained earlier, sodium and potassium contents in different plant parts were determined after digestion, using a Jenway-PFP 7 flame photometer $[9,99]$.

\section{Statistical Analysis}

Two factor factorial analysis under CRD was used to analyze the data with the help of the computer-based software Statistix 8.1 (Tallahassee, FL, USA). There were two factors i.e., species and treatments. Their interaction effect was determined using the ANOVA technique, and the significance of treatments was calculated using Tukey's HSD Test.

\section{Conclusions}

Organic amendments showed a positive effect on the growth of Vachellia nilotica and Dalbergia sissoo under saline conditions. Organic amendments enhanced enzymatic activities, reduced oxidative stress, increased potassium concentration, and decreased sodium concentration, resulting in improved growth of both plant species. At the seedling stage, farmyard manure showed better results for the growth of Vachellia nilotica, whereas biochar was the most effective amendment for the growth of Dalbergia sissoo. A long-term field trial is required to determine field feasibility with cost analysis for planting these trees species under recommended amendments in saline soils. Moreover, the effects of different biochar and farmyard manure levels on the growth of Dalbergia sissoo and V. nilotica should also be tested. The findings of this study can be employed during afforestation and reforestation programs, mainly when performed with the prime objective of saline soil reclamation.

Author Contributions: M.T.B.Y. and G.Y. designed the experiment; M.T.B.Y. performed the experiment and prepared the first draft of the article; M.F.N. supervised the research; S.G. and I.A. helped in estimating physiological parameters; M.Z.-u.-R. helped in soil analysis; M.I. helped in statistical analysis; and X.Q. and S.U.R. provided the funds, proposed the methodology, and visualized the final shape of the manuscript. All authors have read and agreed to the published version of the manuscript. 
Funding: This work was supported by the Higher Education Commission of Pakistan (HEC), which provided funding to Muhammad Talha Bin Yousaf under the Indigenous $5000 \mathrm{Ph}$.D. Fellowship Program (PIN NO. 213-60808-2AV2-166 (50025747). We also express our sincere gratitude to The Agricultural Science and Technology Innovation Program, Chinese Academy of Agricultural Sciences (Grant No. CAAS-ASTIP) and the National Natural Science Foundation of China (Grant No. 51679241) for providing funds for this article.

Institutional Review Board Statement: Not applicable.

Informed Consent Statement: Not applicable.

Data Availability Statement: Data available on request from the corresponding author.

Acknowledgments: We are thankful to nursery staff and laboratory staff of the Department of Forestry, UAF; The Agricultural Science and Technology Innovation Program, Chinese Academy of Agricultural Sciences (Grant No. CAAS-ASTIP); and the National Natural Science Foundation of China (Grant No. 51679241) for supporting this research.

Conflicts of Interest: The authors declare no conflict of interest.

\section{References}

1. Dagar, J.C.; Minhas, P.S. Global perspectives on agroforestry for the management of salt-affected soils. In Agroforestry for the Management of Waterlogged Saline Soils and Poor-Quality Waters; Springer: New Dehli, India, 2016; pp. 5-32.

2. Srivastava, N. Reclamation of saline and sodic soil through phytoremediation. In Environmental Concerns and Sustainable Development; Springer: Singapore, 2020; pp. 279-306.

3. FAO. FAO Soils Portal. Available online: http://www.fao.org/soils-portal/soil-management/management-of-some-problemsoils/salt-affected-soils/more-information-on-salt-affected-soils/en/ (accessed on 2 December 2021).

4. Tripathi, A.D.; Mishra, R.; Maurya, K.K.; Singh, R.B.; Wilson, D.W. Estimates for world population and global food availability for global health. In The Role of Functional Food Security in Global Health; Elsevier: Amsterdam, The Netherlands, 2019; pp. 3-24.

5. Hossain, S. Present scenario of global salt affected soils, its management and importance of salinity research. Int. Res. J. Biol. Sci. 2019, 1, 1-3.

6. Mbarki, S.; Sytar, O.; Cerda, A.; Zivcak, M.; Rastogi, A.; He, X.; Zoghlami, A.; Abdelly, C.; Brestic, M. Strategies to mitigate the salt stress effects on photosynthetic apparatus and productivity of crop plants. In Salinity Responses and Tolerance in Plants; Springer International Publishing: Cham, Switzerland, 2018; Volume 1, pp. 85-136.

7. Gangwar, P.; Singh, R.; Trivedi, M.; Tiwari, R.K. Sodic soil: Management and reclamation strategies. In Environmental Concerns and Sustainable Development; Springer: Singapore, 2020; pp. 175-190.

8. Herr, D.; Blum, J.; Himes-Cornell, A.; Sutton-Grier, A. An analysis of the potential positive and negative livelihood impacts of coastal carbon offset projects. J. Environ. Manag. 2019, 235, 463-479. [CrossRef] [PubMed]

9. Yousaf, M.T.B.; Nawaz, M.F.; Zia ur Rehman, M.; Gul, S.; Yasin, G.; Rizwan, M.; Ali, S. Effect of three different types of biochars on eco-physiological response of important agroforestry tree species under salt stress. Int. J. Phytoremediat. 2021, 23, 1412-1422. [CrossRef] [PubMed]

10. Arora, S. Halotolerant microbes for amelioration of salt-affected soils for sustainable agriculture. In Phyto-Microbiome in Stress Regulation; Springer: Singapore, 2020; pp. 323-343.

11. George, S.J.; Harper, R.J.; Hobbs, R.J.; Tibbett, M. A sustainable agricultural landscape for Australia: A review of interlacing carbon sequestration, biodiversity and salinity management in agroforestry systems. Agric. Ecosyst. Environ. 2012, 163, 28-36. [CrossRef]

12. Meir, M.; Zaccai, M.; Raveh, E.; Ben-Asher, J.; Tel-Zur, N. Performance of Ziziphus jujuba trees correlates with tissue mineral content under salinity conditions. Agric. Water Manag. 2014, 142, 47-55. [CrossRef]

13. Nawaz, M.F.; Yousaf, M.T.B.; Yasin, G.; Gul, S.; Ahmed, I.; Abdullah, M.; Rafay, M.; Tanvir, M.A.; Asif, M.; Afzal, S. Agroforestry status and its role to sequester atmospheric CO2 under semi-arid climatic conditions in Pakistan. Appl. Ecol. Environ. Res. 2018, 16, 645-661. [CrossRef]

14. Sharma, P.C.; Singh, A. Reviving the productivity of salt-affected lands: Technological options, constraints and research needs. In Research Developments in Saline Agriculture; Springer: Singapore, 2019; pp. 591-627.

15. Yasin, G.; Nawaz, M.F.; Martin, T.A.; Niazi, N.K.; Gul, S.; Yousaf, M.T. Bin evaluation of agroforestry carbon storage status and potential in irrigated plains of Pakistan. Forests 2019, 10, 640. [CrossRef]

16. Yousaf, M.T.B.; Nawaz, M.F.; Khawaja, H.F.; Gul, S.; Ali, S.; Ahmad, I.; Rasul, F.; Rizwan, M. Ecophysiological response of early stage Albizia lebbeck to cadmium toxicity and biochar addition. Arab. J. Geosci. 2019, 12, 134. [CrossRef]

17. Edrisi, S.A.; Tripathi, V.; Chaturvedi, R.K.; Dubey, D.K.; Patel, G.; Abhilash, P.C. Saline soil reclamation index as an efficient tool for assessing restoration progress of saline land. Land Degrad. Dev. 2021, 32, 123-138. [CrossRef]

18. Behera, L.; Nayak, M.; Patel, D.; Mehta, A.; Sinha, S.; Gunaga, R. Agroforestry practices for physiological amelioration of salt affected soils. J. Plant Stress Physiol. 2015, 1, 13. [CrossRef] 
19. Yousaf, M.T.B.; Nawaz, M.F.; Zia, M.; Rasul, F.; Tanvir, M.A. Ecophysiological response of early stage Eucalyptus camaldulensis to biochar and other organic amendments under salt stress. Pak. J. Agric. Sci. 2021, 58, 999-1006. [CrossRef]

20. Abbas, G.; Saqib, M.; Akhtar, J.; Basra, S.M.A. Salinity tolerance potential of two acacia species at early seedling stage. Pak. J. Agric. Sci. 2013, 50, 683-688.

21. Kaur, I.; Jadhav, S.K.; Tiwari, K.L.; Quraishi, A. Lead tolerance and its accumulation by a tree legume: Dalbergia sissoo DC. Bull. Environ. Contam. Toxicol. 2018, 101, 506-513. [CrossRef]

22. Devi, P.; Singh, S. Promila phytochemical and pharmacological profiling of Dalbergia sissoo Roxb. Stem. J. Pharmacogn. Phytochem. 2017, 6, 2483-2486.

23. Amadou, I.; Soulé, M.; Salé, A. An overview on the importance of Acacia nilotica (L.) willd. ex del.: A review. Asian J. Res. Agric. For. 2020, 5, 12-18. [CrossRef]

24. Khan, T.F.; Salma, M.U.; Hossain, S.A. Impacts of different sources of biochar on plant growth characteristics. Am. J. Plant Sci. 2018, 9, 1922-1934. [CrossRef]

25. Vibha, J.B.; Shekhawat, N.S.; Mehandru, P.; Dinesh, R. Rapid multiplication of Dalbergia sissoo Roxb.: A timber yielding tree legume through axillary shoot proliferation and ex vitro rooting. Physiol. Mol. Biol. Plants 2014, 20, 81-87. [CrossRef] [PubMed]

26. Devi, S.; Nandwal, A.S.; Angrish, R.; Arya, S.S.; Kumar, N.; Sharma, S.K. Phytoremediation potential of some halophytic species for soil salinity. Int. J. Phytoremediat. 2016, 18, 693-696. [CrossRef] [PubMed]

27. Prabakaran, K.; Li, J.; Anandkumar, A.; Leng, Z.; Zou, C.B.; Du, D. Managing environmental contamination through phytoremediation by invasive plants: A review. Ecol. Eng. 2019, 138, 28-37. [CrossRef]

28. Awan, A.R.; Mahmood, K. Tree plantation in problem soils. In Text Book of Applied Forestry; University of Agriculture: Faisalabad, Pakistan, 2017; pp. 140-159.

29. Banyal, R.; Rajkumar; Kumar, M.; Yadav, R.K.; Dagar, J.C. Agroforestry for rehabilitation and sustenance of saline ecologies. In Agroforestry; Springer: Singapore, 2017; pp. 413-454.

30. Verma, P.; Kumar, M.; Mishra, G.; Sahoo, D. Multivariate analysis of fatty acid and biochemical constitutes of seaweeds to characterize their potential as bioresource for biofuel and fine chemicals. Bioresour. Technol. 2017, 226, 132-144. [CrossRef] [PubMed]

31. Verma, E.; Singh, S.; Niveshika; Mishra, A.K. Salinity-induced oxidative stress-mediated change in fatty acids composition of cyanobacterium Synechococcus sp. PCC7942. Int. J. Environ. Sci. Technol. 2019, 16, 875-886. [CrossRef]

32. Omar, Z.; Bouajila, A.; Bouajila, J.; Rahmani, R.; Besser, H.; Hamed, Y. Spectroscopic and chromatographic investigation of soil organic matter composition for different agrosystems from arid saline soils from Southeastern Tunisia. Arab. J. Geosci. 2020, 13, 524. [CrossRef]

33. Mekuria, W.; Noble, A. The role of biochar in ameliorating disturbed soils and sequestering soil carbon in tropical agricultural production systems. Appl. Environ. Soil Sci. 2013, 2013, 354965. [CrossRef]

34. Oo, A.N.; Iwai, C.B.; Saenjan, P. Soil properties and maize growth in saline and nonsaline soils using cassava-industrial waste compost and vermicompost with or without earthworms. Land Degrad. Dev. 2015, 26, 300-310. [CrossRef]

35. Tully, K.L.; McAskill, C. Promoting soil health in organically managed systems: A review. Org. Agric. 2020, 10, 339-358. [CrossRef]

36. Zhu, H.; Yang, J.; Yao, R.; Wang, X.; Xie, W.; Zhu, W.; Liu, X.; Cao, Y.; Tao, J. Interactive effects of soil amendments (biochar and gypsum) and salinity on ammonia volatilization in coastal saline soil. Catena 2020, 190, 104527. [CrossRef]

37. Nawab, J.; Ghani, J.; Khan, S.; Xiaoping, W. Minimizing the risk to human health due to the ingestion of arsenic and toxic metals in vegetables by the application of biochar, farmyard manure and peat moss. J. Environ. Manag. 2018, 214, 172-183. [CrossRef] [PubMed]

38. Jabeen, N.; Ahmad, R. Growth response and nitrogen metabolism of sunflower (Helianthus annuus L.) to vermicompost and biogas slurry under salinity stress. J. Plant Nutr. 2017, 40, 104-114. [CrossRef]

39. Tejada, M.; Garcia, C.; Gonzalez, J.L.; Hernandez, M.T. Use of organic amendment as a strategy for saline soil remediation: Influence on the physical, chemical and biological properties of soil. Soil Biol. Biochem. 2006, 38, 1413-1421. [CrossRef]

40. Awasthi, M.K.; Sarsaiya, S.; Wainaina, S.; Rajendran, K.; Kumar, S.; Quan, W.; Duan, Y.; Awasthi, S.K.; Chen, H.; Pandey, A.; et al. A critical review of organic manure biorefinery models toward sustainable circular bioeconomy: Technological challenges, advancements, innovations, and future perspectives. Renew. Sustain. Energy Rev. 2019, 111, 115-131. [CrossRef]

41. Wang, L.; Sun, X.; Li, S.; Zhang, T.; Zhang, W.; Zhai, P. Application of organic amendments to a coastal saline soil in North China: Effects on soil physical and chemical properties and tree growth. PLoS ONE 2014, 9, e89185. [CrossRef]

42. Wan, D.; Wu, L.; Liu, Y.; Zhao, H.; Fu, J.; Xiao, S. Adsorption of low concentration perchlorate from aqueous solution onto modified cow dung biochar: Effective utilization of cow dung, an agricultural waste. Sci. Total Environ. 2018, 636, 1396-1407. [CrossRef]

43. Yuan, P.; Wang, J.; Pan, Y.; Shen, B.; Wu, C. Review of biochar for the management of contaminated soil: Preparation, application and prospect. Sci. Total Environ. 2019, 659, 473-490. [CrossRef]

44. He, K.; He, G.; Wang, C.; Zhang, H.; Xu, Y.; Wang, S.; Kong, Y.; Zhou, G.; Hu, R. Biochar amendment ameliorates soil properties and promotes Miscanthus growth in a coastal saline-alkali soil. Appl. Soil Ecol. 2020, 155, 103674. [CrossRef]

45. Cabot, C.; Sibole, J.V.; Barceló, J.; Poschenrieder, C. Lessons from crop plants struggling with salinity. Plant Sci. 2014, 226 , 2-13. [CrossRef] [PubMed] 
46. Gupta, B.; Huang, B. Mechanism of salinity tolerance in plants: Physiological, biochemical, and molecular characterization. Int. J. Genom. 2014, 2014, 701596. [CrossRef] [PubMed]

47. Koubouris, G.C.; Tzortzakis, N.; Kourgialas, N.N.; Darioti, M.; Metzidakis, I. Growth, photosynthesis and pollen performance in saline water treated olive plants under high temperature. Int. J. Plant Biol. 2015, 6, 6038. [CrossRef]

48. Roy, S.J.; Negrão, S.; Tester, M. Salt resistant crop plants. Curr. Opin. Biotechnol. 2014, 26, 115-124. [CrossRef]

49. Bandingan, K.; Tanah, P.; Ke Atas, B.; Gandum, T.; Pengeluaran, D.; Salin-Sodik, T.; Zia-Ur-Rehman, M.; Rizwan, M.; Sabir, M. Comparative effects of different soil conditioners on wheat growth and yield grown in saline-sodic soils. Sains Malays. 2016, 45, 339-346.

50. Khaliq, R.; Tita, O.; Zafar, Z.U. Possible assessment of salt tolerance in ocimum basilicum by chlorophyll fluorescence. Sci. Pap. Ser. Manag. Econ. Eng. Agric. Rural Dev. 2017, 17, 175-182.

51. Mohamed, A.K.S.H.; Qayyum, M.F.; Abdel-Hadi, A.M.; Rehman, R.A.; Ali, S.; Rizwan, M. Interactive effect of salinity and silver nanoparticles on photosynthetic and biochemical parameters of wheat. Arch. Agron. Soil Sci. 2017, 63, 1736-1747. [CrossRef]

52. Parvaiz, A.; Satyawati, S. Salt stress and phyto-biochemical responses of plants-A review. Plant Soil Environ. 2008, 54, 89-99. [CrossRef]

53. Tewari, P.; Saxena, A.K.; Rao, O.P. Effect of sodicity and salinity on seedling growth of two early successional agroforestry tree species. Trop. Ecol. 2006, 47, 125-132.

54. Soliveres, S.; Monerris, J.; Cortina, J. Irrigation, organic fertilization and species successional stage modulate the response of woody seedlings to herbaceous competition in a semi-arid quarry restoration. Appl. Veg. Sci. 2012, 15, 175-186. [CrossRef]

55. Gaur, A.; Adholeya, A. Diverse response of five ornamental plant species to mixed indigenous and single isolate arbuscularmycorrhizal inocula in marginal soil amended with organic matter. J. Plant Nutr. 2005, 28, 707-723. [CrossRef]

56. Wortman, S.E.; Holmes, A.A.; Miernicki, E.; Knoche, K.; Pittelkow, C.M. First-season crop yield response to organic soil amendments: A meta-analysis. Agron. J. 2017, 109, 1210-1217. [CrossRef]

57. Somerville, P.D.; Farrell, C.; May, P.B.; Livesley, S.J. Tree water use strategies and soil type determine growth responses to biochar and compost organic amendments. Soil Tillage Res. 2019, 192, 12-21. [CrossRef]

58. Akhtar, S.S.; Andersen, M.N.; Liu, F. Residual effects of biochar on improving growth, physiology and yield of wheat under salt stress. Agric. Water Manag. 2015, 158, 61-68. [CrossRef]

59. Lashari, M.S.; Ye, Y.; Ji, H.; Li, L.; Kibue, G.W.; Lu, H.; Zheng, J.; Pan, G. Biochar-manure compost in conjunction with pyroligneous solution alleviated salt stress and improved leaf bioactivity of maize in a saline soil from central China: A 2-year field experiment. J. Sci. Food Agric. 2015, 95, 1321-1327. [CrossRef] [PubMed]

60. Oram, N.J.; van de Voorde, T.F.J.; Ouwehand, G.-J.; Bezemer, T.M.; Mommer, L.; Jeffery, S.; van Groenigen, J.W. Soil amendment with biochar increases the competitive ability of legumes via increased potassium availability. Agric. Ecosyst. Environ. 2014, 191, 92-98. [CrossRef]

61. Abrishamkesh, S.; Gorji, M.; Asadi, H.; Bagheri-Marandi, G.H.; Pourbabaee, A.A. Effects of rice husk biochar application on the properties of alkaline soil and lentil growth. Plant Soil Environ. 2016, 61, 475-482. [CrossRef]

62. Liew, R.K.; Chai, C.; Yek, P.N.Y.; Phang, X.Y.; Chong, M.Y.; Nam, W.L.; Su, M.H.; Lam, W.H.; Ma, N.L.; Lam, S.S. Innovative production of highly porous carbon for industrial effluent remediation via microwave vacuum pyrolysis plus sodium-potassium hydroxide mixture activation. J. Clean. Prod. 2019, 208, 1436-1445. [CrossRef]

63. Chowdhury, S.; Bhusan, D.; Hashem, M.A.; Hoque, M.A. Organic amendments for mitigating soil salinity in rice. Res. Agric. Livest. Fish. 2019, 6, 11-17. [CrossRef]

64. Nagasawa, K.; Wang, B.; Nishiya, K.; Ushijima, K.; Zhu, Q.; Fukushima, M.; Ichijo, T. Effects of humic acids derived from lignite and cattle manure on antioxidant enzymatic activities of barley root. J. Environ. Sci. Health Part B 2016, 51, 81-89. [CrossRef]

65. Turan, V. Potential of pistachio shell biochar and dicalcium phosphate combination to reduce Pb speciation in spinach, improved soil enzymatic activities, plant nutritional quality, and antioxidant defense system. Chemosphere 2020, 245, 125611. [CrossRef] [PubMed]

66. Shahkolaie, S.S.; Baranimotlagh, M.; Dordipour, E.; Khormali, F. Effects of inorganic and organic amendments on physiological parameters and antioxidant enzymes activities in Zea mays L. from a cadmium-contaminated calcareous soil. S. Afr. J. Bot. 2020, 128, 132-140. [CrossRef]

67. Ramzani, P.M.A.; Coyne, M.S.; Anjum, S.; Khan, W.-D.; Iqbal, M. In Situ immobilization of Cd by organic amendments and their effect on antioxidant enzyme defense mechanism in mung bean (Vigna radiata L.) seedlings. Plant Physiol. Biochem. 2017, 118, 561-570. [CrossRef]

68. Elshaikh, N.A.; Zhipeng, L.; Dongli, S.; Timm, L.C. Increasing the okra salt threshold value with biochar amendments. J. Plant Interact. 2018, 13, 51-63. [CrossRef]

69. Rezaie, N.; Razzaghi, F.; Sepaskhah, A.R. Different levels of irrigation water salinity and biochar influence on faba bean yield, water productivity, and ions uptake. Commun. Soil Sci. Plant Anal. 2019, 50, 611-626. [CrossRef]

70. Tanure, M.M.C.; da Costa, L.M.; Huiz, H.A.; Fernandes, R.B.A.; Cecon, P.R.; Pereira Junior, J.D.; da Luz, J.M.R. Soil water retention, physiological characteristics, and growth of maize plants in response to biochar application to soil. Soil Tillage Res. 2019, 192, 164-173. [CrossRef] 
71. Meena, M.D.; Yadav, R.K.; Narjary, B.; Yadav, G.; Jat, H.S.; Sheoran, P.; Meena, M.K.; Antil, R.S.; Meena, B.L.; Singh, H.V.; et al. Municipal solid waste (MSW): Strategies to improve salt affected soil sustainability: A review. Waste Manag. 2019, 84, 38-53. [CrossRef]

72. Bhadha, J.H.; Capasso, J.M.; Khatiwada, R.; Swanson, S. Raising Soil Organic Matter Content to Improve Water Holding Capacity; UF/IFAS: Gainesville, FL, USA, 2017; pp. 1-5.

73. Cesarano, G.; De Filippis, F.; La Storia, A.; Scala, F.; Bonanomi, G. Organic amendment type and application frequency affect crop yields, soil fertility and microbiome composition. Appl. Soil Ecol. 2017, 120, 254-264. [CrossRef]

74. Mi, W.; Wu, L.; Brookes, P.C.; Liu, Y.; Zhang, X.; Yang, X. Changes in soil organic carbon fractions under integrated management systems in a low-productivity paddy soil given different organic amendments and chemical fertilizers. Soil Tillage Res. 2016, 163, 64-70. [CrossRef]

75. Niazi, N.K.; Bibi, I.; Shahid, M.; Ok, Y.S.; Shaheen, S.M.; Rinklebe, J.; Wang, H.; Murtaza, B.; Islam, E.; Farrakh Nawaz, M.; et al Arsenic removal by Japanese oak wood biochar in aqueous solutions and well water: Investigating arsenic fate using integrated spectroscopic and microscopic techniques. Sci. Total Environ. 2018, 621, 1642-1651. [CrossRef]

76. Saifullah; Dahlawi, S.; Naeem, A.; Rengel, Z.; Naidu, R. Biochar application for the remediation of salt-affected soils: Challenges and opportunities. Sci. Total Environ. 2018, 625, 320-335. [CrossRef]

77. Trivedi, P.; Singh, K.; Pankaj, U.; Verma, S.K.; Verma, R.K.; Patra, D.D. Effect of organic amendments and microbial application on sodic soil properties and growth of an aromatic crop. Ecol. Eng. 2017, 102, 127-136. [CrossRef]

78. Diacono, M.; Montemurro, F. Effectiveness of organic wastes as fertilizers and amendments in salt-affected soils. Agriculture 2015, 5, 221-230. [CrossRef]

79. Cherubin, M.R.; Chavarro-Bermeo, J.P.; Silva-Olaya, A.M. Agroforestry systems improve soil physical quality in northwestern Colombian Amazon. Agrofor. Syst. 2019, 93, 1741-1753. [CrossRef]

80. Yazdanpanah, N.; Mahmoodabadi, M.; Cerdà, A. The impact of organic amendments on soil hydrology, structure and microbial respiration in semiarid lands. Geoderma 2016, 266, 58-65. [CrossRef]

81. Luo, X.; Liu, G.; Xia, Y.; Chen, L.; Jiang, Z.; Zheng, H.; Wang, Z. Use of biochar-compost to improve properties and productivity of the degraded coastal soil in the Yellow River Delta, China. J. Soils Sediments 2017, 17, 780-789. [CrossRef]

82. Leogrande, R.; Vitti, C. Use of organic amendments to reclaim saline and sodic soils: A review. Arid. Land Res. Manag. 2019, 33, 1-21. [CrossRef]

83. Ali, S.; Rizwan, M.; Qayyum, M.F.; Ok, Y.S.; Ibrahim, M.; Riaz, M.; Arif, M.S.; Hafeez, F.; Al-Wabel, M.I.; Shahzad, A.N. Biochar soil amendment on alleviation of drought and salt stress in plants: A critical review. Environ. Sci. Pollut. Res. 2017, 24, 12700-12712. [CrossRef] [PubMed]

84. Drake, J.A.; Cavagnaro, T.R.; Cunningham, S.C.; Jackson, W.R.; Patti, A.F. Does biochar improve establishment of tree seedlings in saline sodic soils? Land Degrad. Dev. 2016, 27, 52-59. [CrossRef]

85. $\mathrm{Wu}, \mathrm{Y} . ; \mathrm{Xu}, \mathrm{G}$.; Shao, H.B. Furfural and its biochar improve the general properties of a saline soil. Solid Earth $2014,5,665-671$. [CrossRef]

86. Sun, H.; Lu, H.; Chu, L.; Shao, H.; Shi, W. Biochar applied with appropriate rates can reduce N leaching, keep N retention and not increase $\mathrm{NH}_{3}$ volatilization in a coastal saline soil. Sci. Total Environ. 2017, 575, 820-825. [CrossRef] [PubMed]

87. Yu, H.; Zou, W.; Chen, J.; Chen, H.; Yu, Z.; Huang, J.; Tang, H.; Wei, X.; Gao, B. Biochar amendment improves crop production in problem soils: A review. J. Environ. Manag. 2019, 232, 8-21. [CrossRef] [PubMed]

88. Zheng, H.; Wang, X.; Chen, L.; Wang, Z.; Xia, Y.; Zhang, Y.; Wang, H.; Luo, X.; Xing, B. Enhanced growth of halophyte plants in biochar-amended coastal soil: Roles of nutrient availability and rhizosphere microbial modulation. Plant. Cell Environ. 2018, 41,517-532. [CrossRef]

89. Husien, A. Effect of biochar, farmyard manure and nitrogen fertilizers on soil chemical properties in Sinana District, South Eastern Oromia, Ethiopia. Int. J. Appl. Agric. Sci. 2017, 3, 148. [CrossRef]

90. McGeorge, W.T. Diagnosis and improvement of saline and alkaline soils. Soil Sci. Soc. Am. J. 1954, 18, 348. [CrossRef]

91. Bouyoucos, G.J. Hydrometer method improved for making particle size analyses of soils 1. Agron. J. 1962, 54, 464-465. [CrossRef]

92. Sikora, L.J.; Moore-Kucera, J. Soil Test Methods from the Southeastern United States; University of Georgia College of Agricultural \& Environmental Sciences: Athens, GA, USA, 2014; Volume 419, ISBN 9798624955.

93. Ur Rahman, S.; Xuebin, Q.; Yasin, G.; Cheng, H.; Mehmood, F.; Zain, M.; Shehzad, M.; Ahmad, M.I.; Riaz, L.; Rahim, A.; et al. Role of silicon on root morphological characters of wheat (Triticum aestivum L.) plants grown under Cd-contaminated nutrient solution. Acta Physiol. Plant. 2021, 43, 60. [CrossRef]

94. Rahman, S.U.; Xuebin, Q.; Riaz, L.; Yasin, G.; Shah, A.N.; Shahzad, U.; Jahan, M.S.; Ditta, A.; Bashir, M.A.; Rehim, A.; et al. The interactive effect of $\mathrm{pH}$ variation and cadmium stress on wheat (Triticum aestivum L.) growth, physiological and biochemical parameters. PLOS ONE 2021, 16, e253798. [CrossRef] [PubMed]

95. Ur Rahman, S.; Xuebin, Q.; Kamran, M.; Yasin, G.; Cheng, H.; Rehim, A.; Riaz, L.; Rizwan, M.; Ali, S.; Alsahli, A.A.; et al. Silicon elevated cadmium tolerance in wheat (Triticum aestivum L.) by endorsing nutrients uptake and antioxidative defense mechanisms in the leaves. Plant Physiol. Biochem. 2021, 166, 148-159. [CrossRef] [PubMed] 
96. Ur Rahman, S.; Xuebin, Q.; Zhao, Z.; Du, Z.; Imtiaz, M.; Mehmood, F.; Hongfei, L.; Hussain, B.; Ashraf, M.N. Alleviatory effects of Silicon on the morphology, physiology, and antioxidative mechanisms of wheat (Triticum aestivum L.) roots under cadmium stress in acidic nutrient solutions. Sci. Rep. 2021, 11, 1958. [CrossRef] [PubMed]

97. Shafeeq-ur-Rahman; Xuebin, Q.; Yatao, X.; Ahmad, M.I.; Shehzad, M.; Zain, M. Silicon and its application methods improve physiological traits and antioxidants in Triticum aestivum (L.) under cadmium stress. J. Soil Sci. Plant Nutr. 2020, 20, $1110-1121$. [CrossRef]

98. Aebi, H. Catalase in vitro. In Methods in Enzymology; Elsevier: Amsterdam, The Netherlands, 1984; pp. $121-126$.

99. Ur Rehman, M.Z.; Rizwan, M.; Rauf, A.; Ayub, M.A.; Ali, S.; Qayyum, M.F.; Waris, A.A.; Naeem, A.; Sanaullah, M. Split application of silicon in cadmium (Cd) spiked alkaline soil plays a vital role in decreasing Cd accumulation in rice (Oryza sativa L.) grains. Chemosphere 2019, 226, 454-462. [CrossRef] 